\title{
Derivative Misconduct and Forms thereof: \\ Western Refinery Ltd v Hlebela 201536 ILJ 2280 \\ (LAC)
}

TC Maloka*

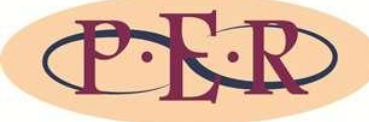

Author

Tumo Charles Maloka

Affiliation

University of Fort Hare,

South Africa

Email tmaloka@ufh.ac.za

Date published 16 August 2016

Editor Prof C Rautenbach

How to cite this article

Maloka TC "Derivative Misconduct and Forms thereof: Western

Refinery Ltd v Hlebela 201536 ILJ 2280 (LAC)" PER / PELJ 2016(19)

- DOI

http://dx.doi.org/10.17159/1727-

3781/2016/v19i0a733

Copyright

\section{(i)}

DOI

http://dx.doi.org/10.17159/17273781/2016/v19i0a733

\begin{abstract}
Western Platinum Refinery Ltd v Hlebela 201536 ILJ 2280 (LAC) ("Hlebela") required the Labour Appeal Court to grapple with difficult questions presented by a generic dilemma which confronts an employer who is faced with clear evidence of recurrent theft of precious minerals but is unable to identify the actual culprits, nor are the employees disposed or willing to cooperate with the employer in tracking down the perpetrator(s). Suddenly, the police informed the employer that an employee who had accumulated wealth was a person of interest in their investigations. However, they could give no information about the employee's being engaged, to their knowledge, in particular illegal activities.

Hlebela answered the nagging question: what is the appropriate way to discipline an employee who has actual knowledge of the wrongdoing of others or who has actual knowledge of information which the employee subjectively knows is relevant to unlawful conduct against the employer's interests? The categorical answer is that the employer should charge the employee with material breach of the duty of good faith, particularising the knowledge allegedly possessed and alleging a culpable non-disclosure.
\end{abstract}

\section{Keywords}

Culpable non-disclosure; derivative misconduct; duty of good faith; collective misconduct; team misconduct; irregular wealth acquisition. 


\section{Introduction}

Modern management decision-making processes in disciplinary matters face the ultimate dilemma when serious acts of misconduct have either been perpetrated or are currently being perpetrated but the employer is not in a position to pinpoint the specific culprit(s). If employees are neither disposed nor willing to co-operate with the employer in tracking down those actually responsible for the misconduct, the problem is of a significantly broader scope. Assume you are the management of a platinum refinery which for several years has been experiencing on-going losses of stock. Out of the blue, the SAPS informs you that one of your employees is a person of interest in police investigations. They give no information about the employee's being engaged, to their knowledge, in particular illegal activities. Rather, the police give you information about the "wealth" amassed by the employee in question and his immediate family. The wealth acquired by the employee in question and his close family is disproportionate to his modest salary; thus, the only logical, natural and plausible explanation for such affluence is that it was sourced from the proceeds of the theft of platinum.

In the particular case sophisticated security surveillance was placed on the suspected employee and the police information was used to track down the assets known to be possessed by the employee or members of his family. Company management also chose to examine the employer's security clocking systems. A compendium of the suspected employee's movements for several days revealed frequent movements through different sections of the plant, including sections in which he had no clearly apparent reason to be. What was particularly disturbing was the fact that the employee had a card that allowed him entry into sites which he was ostensibly forbidden to visit.

What should the employer do in view of the employee's suspicious movements? How should the employer formulate disciplinary charges against the alleged culprit? Can the employer charge the employee with culpable involvement in theft and the non-disclosure of information about wrongdoing? Is derivative misconduct the appropriate charge against the employee for not disclosing his personal financial information, which the employer suspected would implicate him in irregular wealth acquisition? In Western Platinum Refinery Ltd v Hlebela ${ }^{1}$ Sutherland JA was confronted

* Tumo Charles Maloka. BA LLB LLM (UCT). Senior Lecturer, Nelson R Mandela School Law, University of Fort Hare. Email: tmaloka@ufh.ac.za. The author wishes to thank Professor Chuks Okpaluba for sharing an unpublished paper entitled "Current Issues of Fair Procedure in Employer's Disciplinary Enquiry I", presented at 
with a similar hydra-headed problem: what is the appropriate way to discipline an employee who has actual knowledge of the wrongdoing of others or who has actual knowledge of information which the employee subjectively knows is relevant to unlawful conduct against the employer's interests?

\section{The issues in the Hlebela case}

In Hebela, Sutherland JA gave the court's answer to such a management dilemma. The scenario delineated above was the exact situation that arose in Hlebela. The employee, an operator at the appellant's platinum refinery, was charged in the terms described above, with culpable involvement in the theft and with the non-disclosure of information about wrongdoing. The charge for which he was dismissed is better reproduced than paraphrased: It reads as follows:

It is alleged that you have knowledge of the enormous losses of PMGS at PMR but you made no full and frank disclosure to PMR about what you know that could assist PMR in its investigations herein.

The reference to PMR is to the employer, and PMGS refers to Platinum Group Metals. The "losses" refer to unexplained losses of stock over decades. The employee was charged and tried in a disciplinary hearing on an additional charge of culpable participation in the theft of PMGs. He was acquitted on the charge of culpable participation in the theft of PMGs on the basis that evidence of his wealth did not prove culpable participation in the theft.

At arbitration the dismissal of Hlebela was held to be fair. The employee took the arbitrator's award on review and the Labour Court overturned the arbitrator's finding and declared that the dismissal was substantively unfair, but considered reinstatement an inappropriate remedy, and instead granted compensation equivalent to 12 months' salary. The mixed result satisfied neither the employee nor the employer. Accordingly, the employer appealed against the decision setting aside the arbitration award, and the employee, in turn, cross-appealed against the compensation order, seeking a substituted order of reinstatement. The focal issue in Hlebela was the substantive

the workshop on Unfair Dismissals at the 12th Annual Labour Law Conference held in Durban 30 June - 2 July 1999. I would also like thank Professor Patrick Osode credit for his comments and encouragement. Without a detailed critique from two anonymous reviewers, this note would not be possible. The usual disclaimer applies. Western Refinery Ltd v Hlebela 201536 ILJ 2280 (LAC) ("Hlebela"). 
fairness of a conviction for misconduct allegedly perpetrated by the respondent.

\section{The meaning of the term derivative misconduct}

Before turning to the fact-specific issues arising for determination, Sutherland JA found it imperative to deal with the elusive concept of "derivative misconduct", which is interwoven with the non-disclosure species of that concept, "because ... serious confusion existed among those responsible for instituting disciplinary process about the concept and how to apply it appropriately". ${ }^{2}$ Elucidating the distinction between the relevant terms is particularly significant because it is difficult to draw a distinction between the interrelated concepts of common purpose ${ }^{3}$ collective guilt, ${ }^{4}$ collective misconduct ${ }^{5}$ and team misconduct. Divergent opinions have been expressed in an array of cases concerning the interpretation of these terms. ${ }^{6}$

The genesis of the concept of derivative misconduct ${ }^{7}$ and the entry into the South African labour law lexicon of the phrases "derived justification" and "derived violation of trust and confidence" can be traced to the seminal case of Chauke $v$ Leeson Motors. ${ }^{8}$ Cameron JA (as he then was) with customary lucidity pertinently captured the difficult problem of fair employment practice by posing the following question: "Where misconduct necessitating disciplinary action is proved, but management is unable to pinpoint the perpetrator or perpetrators, in what circumstances will it be permissible to dismiss a group of workers which incontestably includes them?"I In that case, the real issue was the reliable identification of the culprits who committed several acts of sabotage over a period of time. The management was unable to pinpoint the perpetrators. A request to the staff to divulge the relevant information was issued to avoid any further sabotage but drew no

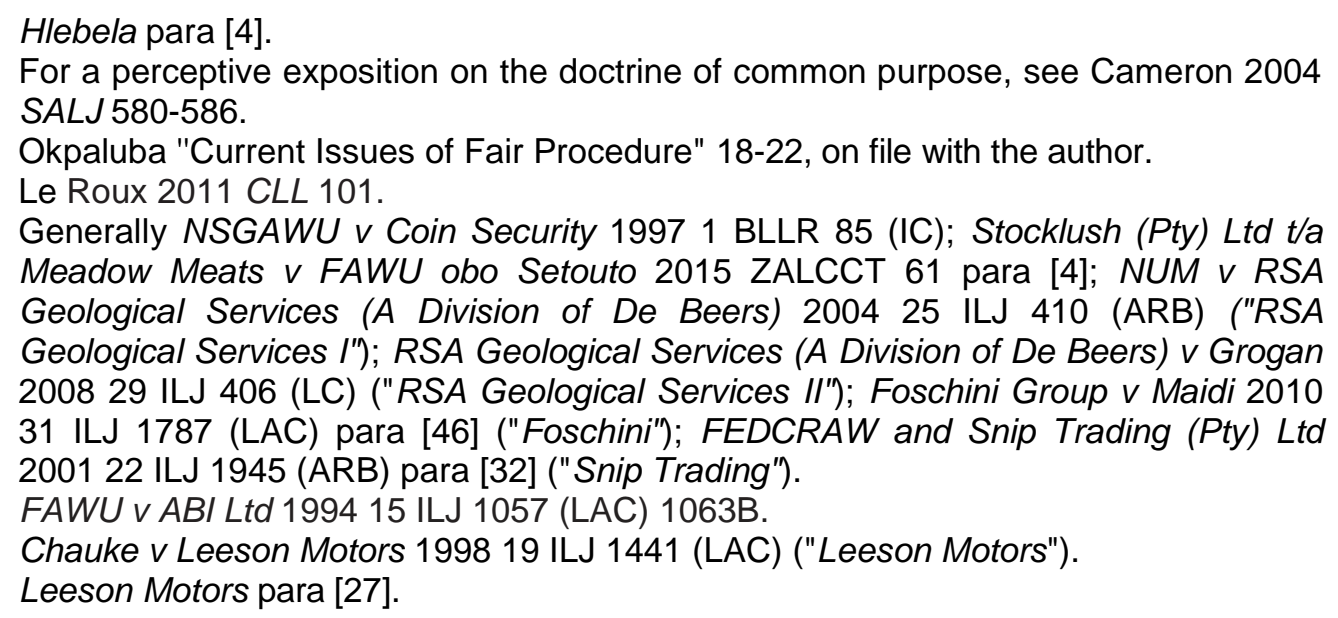


response. Eventually, an ultimatum was issued that any further sabotage in respect of which the individual perpetrators remained unidentified would result in the dismissal of all employees. In the end, the entire workforce was dismissed. The dismissal was upheld by the Industrial Court and on appeal. In upholding the dismissal, the Labour Court noted that it was properly to be inferred that the 20 workers were culpably involved in the "primary misconduct", i.e. the actual acts of sabotage. Sutherland JA explained that the judgement did not necessary imply that the evidence did not warrant a conclusion that each and every worker physically sabotaged a vehicle in the workshop "but that all had associated themselves with the sabotage: an instance of common purpose". ${ }^{10}$

In coming to the conclusion that the employer could not be blamed for treating the misconduct as a collective issue, the court had approached the problem from two angles, a strategy which no doubt took a cue from the Appellate Division's earlier approach with regard to collective dismissals in strike situations. ${ }^{11}$ The first category in the Labour Appeal Court's formulation is where one of only two employees is known to have been involved in "major irreversible destructive action" but management is unable to pinpoint which of them is responsible for the act. In this instance, the employer may be entitled to dismiss both of them, including the innocent one, where all avenues of investigation have been exhausted. The rationalisation here is that of operational requirement, namely that action is necessary to save the life of the enterprise.

The second category results in dismissal on the ground of misconduct where management may have sufficient grounds for inferring that the whole group is responsible for the misconduct or is involved in it. In postulating a two-fold justification in this regard, the Court created an implied duty on an employee in such a group, including the actual perpetrators, to assist management in bringing the guilty to book, a duty akin to that of exemplifying the trust and confidence essential to the employment relationship, a breach of which in itself justifies dismissal. ${ }^{12}$ In Leeson Motors Cameron JA further held that this derived justification is wide enough "to encompass those innocent of it, but who through their silence make themselves guilty of a derivative violation of

\footnotetext{
10 Hlebela para [6].

11 NUMSA v Vetsak Co-operative 19966 BLLR 697 (A) 717G-H with the famous theme: "The workers acted collectively. Vetsak responded collectively". Also see Professor Brassey's popular aphorism: "the collective must be dealt with collectively" in MAN Truck \& Bus (SA) (Pty) Ltd v United African Motor \& Allied Workers Union 199112 ILJ 181 (Arb) 192F-H; Zondi v The President of the Industrial Court 19978 BLLR 984 (LAC) 1002A-D.

12 Leeson Motors para [33].
} 
trust and confidence". ${ }^{13}$ In effect, the price the innocent pays in this circumstance is for choosing to exercise his or her right to remain silent. The second justification in respect of this category of misconduct is the inference of involvement whereby the employer is entitled to infer that all the employees either participated in the misconduct or lent their support to it positively or passively. ${ }^{14}$ In both of these instances, the employer is entitled to discipline the employees for misconduct as a group.

In RSA Geological Services ${ }^{15}$ Grogan established that proof of derivative misconduct is subject to two requirements: first, that the employee knew or could have acquired knowledge of the wrongdoing, and second, that the employee failed without justification to disclose that knowledge to the employer, or to take reasonable steps to help the employer to acquire that knowledge. Considering the requirements for proof of derivative misconduct espoused by Grogan in RSA Geological Services I, Sutherland JA noted that "the notion that breach of good faith occurs if an employee 'could have acquired knowledge of wrongdoing'" seems to be "too broadly or loosely stated". ${ }^{16}$ While he properly recognised that "negligent ignorance of circumstances of which an employee ought to have been aware should found a basis for culpability within the compass of negligence itself rather than intrude into the realm of breaches of good faith", he then articulated the applicable threshold in the following way: ${ }^{17}$

\begin{abstract}
... actual knowledge is required to trigger the duty to speak up, the employer must prove actual knowledge not merely putative knowledge, and no room exists for considerations of negligent ignorance. Secondly, the notion that a refusal to disclose, pursuant to a duty of good faith, might be capable of justification in order to avoid guilt of a breach of the duty of good faith, seems to me to be incorrect. Logically, there is no room for such defence ... the explanation for non-disclosure may afford, in a given case, mitigation of the culpability, but it would not stretch to a defence to the charge.
\end{abstract}

In RSA Geological Services I/ Pillay J, dealing with the nature of derivative misconduct, observed that "the employer must prove on a balance of probabilities that the employees knew or must have known about the principal misconduct and elected without justification not to disclose what they knew". ${ }^{18}$

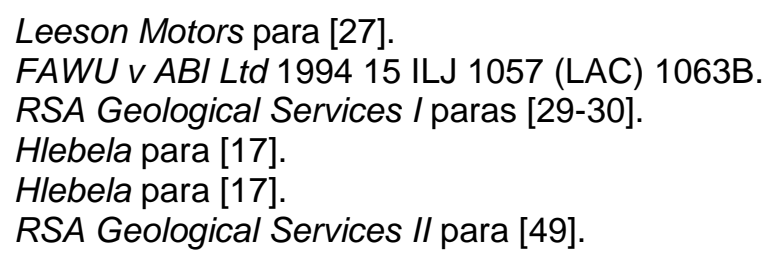


The intriguing question then becomes what is the appropriate way to discipline an employee who has actual knowledge of the wrongdoing of others or who has actual knowledge of information which the employee subjectively knows is relevant to unlawful conduct against the employer's interests? To a question of this nature there is only one possible answer, according to Sutherland JA: ${ }^{19}$

... to charge that employee with material breach of the duty of good faith, particularising the knowledge allegedly possessed and alleging a culpable non-disclosure. This observation does not mean that the gravamen of such a charge might not also be articulated in another way, provided it is plain what is alleged and why it is alleged to be culpable.

If we return to the facts and merits of the case against Hlebela, it is important to recall that the disciplinary outcome was that the evidence of his wealth did not prove his culpable participation in the theft. He was, however, convicted of the non-disclosure charge. Apparently the "information" not divulged, relied upon to convict him, was information specified in demands, made to him after he had been charged, to reveal details of his personal financial affairs. He declined, acting on the union advice that he was under no obligation to do so.

For an employer to make ex post facto demands to the employee to disclose information about his or her personal finances in order to substantiate a charge of non-disclosure is perhaps more problematic than appears at first sight. After all, Hlebela is somewhat unusual in that the demands made to reveal personal information were not for the sort of information that would constitute the substance of culpable non-disclosure pursuant to a duty of good faith. It is arguable that a resort to undisclosed information relied on to validate the charge was not about wrongdoing and resulting stock losses, but about his personal wealth. It seems correct to assert that the demands made to disclose personal information were in the nature of a demand for the discovery of information which ought to be ventilated in the disciplinary hearing, or at least in the arbitration.

The difficulty of grasping what the prosecutors in the disciplinary enquiry could have had in mind when the charge was put to the employee weighed heavily with the Labour Appeal Court:20

Even an unreasonable refusal to disclose the employee's personal finances and a reasonable inference that he did so to conceal the manner of their acquisition is not capable of being logically linked to the fact that he has

19 Hlebela para [20].

20 Hlebela para [28]. 
actual knowledge of wrongdoing by others. When the employer is thwarted by a non-disclosure to procure information, it cannot be argued that the employer can infer proof of what it suspects.

The issues posed by the ex post facto demand that the employee reveal his personal financial affairs can be seen as part of the frailties in the employer's evidence to warrant dismissal for culpable non-disclosure. In the present case, the Labour Appeal Court noted that

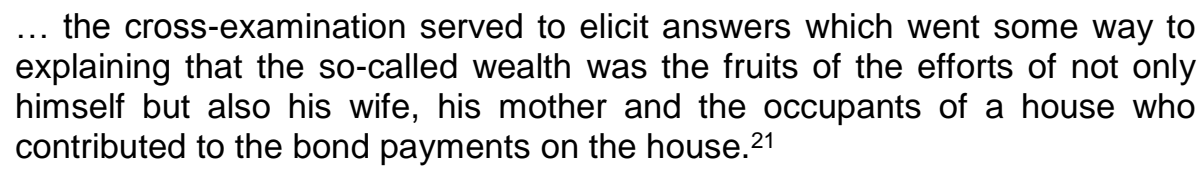

There can be no doubt that the explanations proffered by the employee may have been evasive and inadequate, but it is also manifestly plain that the inadequacy of the evidential material implicating Hlebela fatally undermined the prosecution case. Asking about the employee's suspicious movements around and about the plant did not yield any incriminating evidence concerning the alleged "network" with other co-conspirators. One reason for this was that it was downright speculation. There was no compelling case against the employee. As Sutherland JA wryly observed, "Even cross-examiners need more than straw if they are asked to make bricks".22

So, in Hlebela it was held that the award convicting him was one no reasonable arbitrator could have reached upon a proper appreciation of the evidence adduced. After the award was set aside, that left the issue of relief and cross-appeal for determination. It may be recalled that the employee cross-appealed against the compensation order and sought an order of reinstatement.

It is important to stress that the conclusion arrived at in respect of refusing reinstatement was premised on what the court below considered to be the employee's manifest deceit as revealed during cross-examination. It is well established that reinstatement is not a competent remedy where dishonesty is involved as it generally results in the irretrievable breakdown of the trust relationship rendering continued employment intolerable. ${ }^{23}$

A careful perusal of the record showed that the factual foundation upon which the Labour Court had based its conclusion was unsound. For

21 Hlebela para [29].

22 Hlebela para [29].

23 For serious reflection on this topic see Okpaluba 1999 SALJ 116; Smit 2011 De Jure 49; Rycroft 2012 ILJ 2271. 
instance, the judge in the court below had held that Hlebela contradicted himself by denying he had a business, but when the name of Ceba Construction Products CC was put to him, he conceded that he was the owner. If this was so, then Hlebela lied, and when caught out he was forced to retract his lie. What lay behind the faulty conclusion of the Labour Court was the pervasive obfuscation about what was being asked and what the answers were supposedly addressing. To illustrate, "the answer 'no' is probably given to the question about what means other than his wages does he have, and was not offered to the question about having another business". ${ }^{24}$ Since the decision of the Labour Court to decline reinstatement rested on shaky foundation, the Labour Appeal Court concluded that re-instatement was the appropriate remedy. This writer would not dissent from this, since the Labour Court's factual determination that the employee was dishonest was not borne out by the evidence.

\section{Commentary}

Hlebela is by far the most important decision on the thorny issue of derivative misconduct and its forms since Leeson Motors. If the employer proceeds by way of derivative misconduct, the employees' misconduct is founded in the fact that the non-participating employees, by failing to take positive action and assisting their employer so that those employees that actually participated in the unlawful behaviour could be brought to book, breached their duty of good faith and trust towards their employer. ${ }^{25}$ By contrast, if the employer opts for the path of culpable non-disclosure, the misconduct is predicated on the general duty of good faith to disclose the wrongdoing of others, not on culpable participation, even in a lesser degree than the other perpetrators. These two authorities, alongside RSA Geological Services I and II; and SAMWU obo Abrahams v City of Cape Town ${ }^{26}$ furnish the ground rules for derivative misconduct, collective misconduct, team misconduct and culpable non-disclosure. The common thread running through these cases is the emphasis on the significance of

24 Hlebela para [36].

25 The emergence of an expansive duty to act in good faith is a reflection of the employee's vulnerable position within inherently asymmetric contractual relation with the employer. In the context of larger trends it partly correlates with the accumulating assault on the pro-regulatory stance of labour law. For an overview of a range of sources exploring this theme, see generally, Klare 1981 Berkeley J Emp \& Lab L 450-482; Klare 1985 Md L Rev 731-840 and Klare "Countervailing Workers' Power" 63; Epstein 1983 Yale LJ 1357; Stone 2001 UCLA L Rev 519; Collins 2001 ILJ (UK) 17; Mitchell Redefining Labour Law; Deakin and Wilkinson Law of the Labour Market; Arup et al Labour Law.

26 SAMWU obo Abrahams v City of Cape Town 201111 BLLR 1106 (LC) ("SAMWU obo Abrahams"). 
proving on a balance of probabilities that the employees knew or must have known about the primary misconduct and opted without justification not to divulge what they knew.

As already noted, derivative misconduct cannot diminish the standard of proof an employer must still comply with to establish the existence of misconduct. ${ }^{27}$ The central issue is that employees against whom derivative misconduct is invoked must be properly identified. An instructive but simple illustration is provided by Snyman AJ in SATAWU v Collet Armed Security Services CC: $: 28$

Assuming an employer has 100 employees and during a strike some employees participated in unlawful behaviour. Does this now mean that all employees, just because they are employed by the same employer and may have participated in the strike, can now be held accountable for this misconduct by certain individuals on the basis of derivative misconduct just because they are all employed by the same employer and participated in the same strike? Surely not. What if a particular group of employees were not even present when the unlawful behaviour took place and never witnessed or was aware of the same?

This is perhaps seen as the dividing line between derivative misconduct and collective guilt in that the application of derivative misconduct requires that individual employees must at least still be given the opportunity to explain why they should not be held accountable in terms thereof.

The judgement in Hlebela authoritatively elucidated the abstract issue of justified dismissal for non-disclosure which was not dealt with in respect of Leeson Motors. The real issue in matters concerning culpable nondisclosure is that the undisclosed knowledge must be actual and not imputed or constructive knowledge of wrongdoing. Proof of actual knowledge is likely to be established by drawing inferences from the evidence adduced. Therefore non-disclosure must be deliberate. Accordingly, actual knowledge of wrongdoing triggers a duty to disclose. If there has been a request for information about known wrongdoing or suspected wrongdoing, culpability for non-disclosure is simply aggravated.

Aside from clarifying the distinction between derivative misconduct and culpable non-disclosure, Hlebela invites consideration of the impossible distinction between the notions of collective guilt, collective misconduct and team misconduct. It is worth bearing in mind that item $7(\mathrm{a})$ of the Code of Good Practice requires the employer to prove on a balance of

27 NUM $v$ Besent, Grogan $v$ RSA Geological Services (A Division of De Beers Consolidated Mines Ltd) 2010 ZALAC 12 paras [54-58] ("Besent").

28 SATAWU v Collet Armed Security Services CC 2013 ZALCJHB 301 para [61]. 
probabilities that the employee was actually guilty of misconduct. This may be easily accomplished in some cases and prove impossible in others. The proof is particularly difficult in cases where several employees are involved in the same misconduct, as in collective misconduct. In such circumstances, it is required that it be proved on a balance of probabilities that each employee was actually involved before disciplinary action can be taken against them. In other words, this means that there needs to be established that the employee was actually involved and that no one should be convicted of misconduct in the absence of discernible proof that the employee was involved in the identified acts, merely because he or she was part of a collective.

One should perhaps not be surprised that those responsible for initiating disciplinary proceedings have found these concepts fraught with misconception. In this writer's view, the very existence of derivative misconduct, collective misconduct and team misconduct is a reflection of the need to develop innovative ways of navigating the need to deal with collective guilt. According to one line of reasoning, the employer cannot dismiss the workers collectively because the concept of collective guilt is "wholly foreign to our system and repugnant to the requirements of natural justice". ${ }^{29}$ The main objection to the collective guilt approach is that those employees who did not participate in the unlawful act or who did not associate themselves with the behaviour of the perpetrators will be punished along with the wrongdoers. The consequence therefore is that the collective guilt approach endorses the dismissal of innocent employees.

SAMWU obo Abrahams required the court to consider whether the guilt of a group of employees in respect of a road blockade could be inferred from the fact that they were present at the Cape Town Civic Centre and had given no plausible explanation of how they got there. In this case the applicant union had mobilised its members and planned to move in a convoy along the N2 to the Civic Centre. The plan was carried out as intended. However, the identification of the employees partaking in the unlawful work stoppage could be made only at the Civic Centre. The respondent dealt with the matter from a collective misconduct approach and the dismissed applicants were accorded the opportunity at the disciplinary enquiry to explain why collective dismissal should not be applied to them. They declined to do so, relying on the union's advice. It was held that the dismissal of the applicants was not unfair as they acted

$29 \quad$ NSGAWU $v$ Coin Security 19971 BLLR 85 (IC) 91F-G ("NSCAWU"). See also NUM $v$ Durban Deep Roodepoort Ltd 19878 ILJ 156 (IC). 
as a cohesive group with a common purpose. It was reasonable to find that on a balance of probabilities the applicants had been involved in the event along the N2 freeway.

A useful way to explore the impossible distinction between the collective guilt approach on the one hand and collective misconduct and team misconduct on the other is to review the authorities concerning stock loss (the so called "shrinkage action plan") and collective team control, where it is possible to hold individual employees liable as a group. In line with this reasoning, what Item 9 of the Code of Good Practice requires in terms of a charge of poor work performance, it is contended, is that the employee be made aware that he/she has failed to meet the standard of performance set by the employer and that he/she be given the opportunity to meet that standard, failing which dismissal will follow as an appropriate sanction. ${ }^{30}$

Grogan has written extensively on and refined the concept of team misconduct ${ }^{31}$ and handed down seminal arbitration awards. ${ }^{32}$ In situations of team misconduct Grogan points out that it is permissible to act against the entire team if each member has a role to play in attaining the performance standard set for the team. If the standard is not attained each member must be given an opportunity to explain the team's failure; the person to whom the explanations are given must be objectively satisfied that the team's failure cannot be blamed on any particular member of that team. ${ }^{33}$ The rationale for this approach is that it is often extremely difficult to prove that stock losses are caused by a particular employee. ${ }^{34}$ In the case of Foschini, five employees were charged and dismissed for collective misconduct for failing to secure company assets, in the wake of massive shrinkage. Relying on the notion of team misconduct espoused in Snip Trading, the arbitrator concluded that if employees' in a small store are unable to give an explanation for massive stock loss other than saying it was beyond their control, the only logical inference is that they are guilty. The arbitrator's conclusion that such a policy was not unfair was upheld by the Labour Appeal Court. On this analysis, the employees are held accountable for a general stock loss because an employer is entitled to introduce strict rules in order to safeguard its assets.

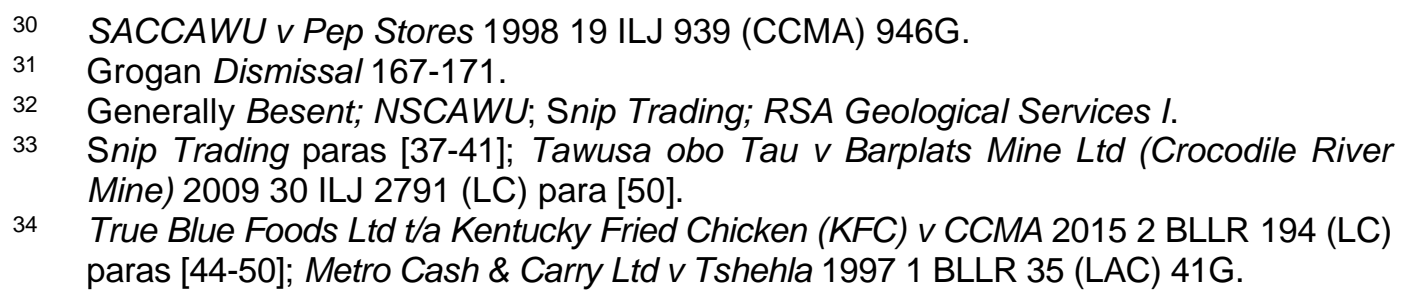

34 True Blue Foods Ltd t/a Kentucky Fried Chicken (KFC) v CCMA 20152 BLLR 194 (LC) paras [44-50]; Metro Cash \& Carry Ltd v Tshehla 19971 BLLR 35 (LAC) 41G. 


\section{Conclusion}

There can be no doubt that the issues in Hlebela are illustrative of the employee's all-encompassing duty of good faith to rat on the culprits. It can be seen from the preceding discussion that those in charge of the disciplinary process struggled to come to grips with the interrelated concept of derivate misconduct and culpable non-disclosure. Hlebela provides guidance on how to formulate disciplinary charges against an employee who has actual knowledge of the wrongdoing of others or who has actual knowledge of information which the employee subjectively knows is relevant to unlawful conduct against the employer's interests. In such a situation, the employee can be charged with a material breach of the duty of good faith, particularising the knowledge allegedly possessed and alleging a culpable non-disclosure. Often the wrongdoing in itself might not be known to the employer. It follows that the disclosure of information relevant to the wrongdoing, pursuant to the duty of good faith, is not dependent upon a specific request for relevant information. Conversely, where a request for information about known transgression or suspected transgressions has in fact been made, culpability for the non-disclosure is simply aggravated. In short, the overarching principle to be derived from the judgement of Sutherland JA is that non-disclosure may afford, in a given case, mitigation of the culpability, but is per se not a defence to a charge of a breach of a duty of good faith.

\section{Bibliography}

\section{Literature}

Arup et al Labour Law

Arup C et al (eds) Labour Law and Labour Market Regulation: Essays on the Construction, Constitution and Regulation of Labour Markets and Work Relationships (Federation Press Sydney 2006)

Cameron 2004 SALJ

Cameron E "When Judges Fail Justice" 2004 SALJ 580-594

Collins 2001 ILJ (UK)

Collins H "Regulating the Employment Relation for Competitiveness" 2001 ILJ (UK) 17-48 
Deakin and Wilkinson Law of the Labour Market

Deakin SF and Wilkinson F The Law of the Labour Market: Industrialization, Employment, and Legal Evolution (Oxford University Press Oxford 2005)

Epstein 1983 Yale LJ

Epstein R "A Common Law for Labour Relations: A Critique of the New Deal Legislation" 1983 Yale LJ 1357-1408

Grogan Dismissal

Grogan J Dismissal (Juta Cape Town 2002)

Klare 1981 Berkeley J Emp \& Lab L

Klare K "Labour Law as Ideology: Toward a New Historiography of Collective Bargaining" 1981 Berkeley J Emp \& Lab L 450-482

Klare 1985 Md L Rev

Klare K "Traditional Labour Law Scholarship and the Crisis of Collective Bargaining Law: A Reply to Professor Finkin" 1985 Md L Rev 731-840

Klare "Countervailing Workers' Power"

Klare K "Countervailing Workers' Power as a Regulatory Strategy" in Collins H, Davies P and Rideout RW (eds) Legal Regulation of the Employment Relation (Kluwer London 2000) 63-82

Le Roux 2011 CLL

Le Roux PAK "Group Misconduct: When Will Dismissal be a Fair Remedy for Employers?" 2011 CLL 101-109

Mitchell Redefining Labour Law

Mitchell R (ed) Redefining Labour Law: New Perspectives on the Future of Teaching Research (Centre for Employment and Labour Relations Law Parkville 1995)

Okpaluba 1999 SALJ

Okpaluba C "Reinstatement in Contemporary South African Law of Unfair Dismissal: The Statutory Guidelines" 1999 SALJ 116-847

Okpaluba "Current Issues of Fair Procedure"

Okpaluba C "Current Issues of Fair Procedure in Employer's Disciplinary Enquiry I". Unpublished paper presented at the Workshop on Unfair Dismissals at the 12th Annual Labour Law Conference (30 June - 2 July 1999 Durban) 
Rycroft 2012 ILJ

Rycroft A "The Intolerable Relationship" 2012 ILJ 2271-2287

Smit 2011 De Jure

Smit N "How Do You Determine a Fair Sanction? Dismissal as Appropriate Sanction in Cases for (Mis)conduct" 2011 De Jure 49-73

Stone 2001 UCLA L Rev

Stone $\mathrm{K}$ "The New Psychological Contract: Implications of the Changing Workplace for Labour and Employment" 2001 UCLA L Rev 519-661

\section{List of cases}

Chauke v Leeson Motors 199819 ILJ 1441 (LAC)

FAWU v ABI Ltd 199415 ILJ 1057 (LAC)

FEDCRAW and Snip Trading (Pty) Ltd 200122 ILJ 1945 (ARB)

Foschini Group v Maidi 201031 ILJ 1787 (LAC)

MAN Truck \& Bus (SA) (Pty) Ltd v United African Motor \& Allied Workers Union 199112 ILJ 181 (Arb)

Metro Cash \& Carry Ltd v Tshehla 19971 BLLR 35 (LAC)

NSGAWU v Coin Security 19971 BLLR 85 (IC)

NUM $v$ Besent, Grogan v RSA Geological Services (A Division of De Beers Consolidated Mines Ltd) 2010 ZALAC 12

NUM v Durban Deep Roodepoort Ltd 19878 ILJ 156 (IC)

NUM v RSA Geological Services (A Division of De Beers) 200425 ILJ 410 (ARB)

NUMSA v Vetsak Co-operative 19966 BLLR 697 (A)

RSA Geological Services (A Division of De Beers) v Grogan 200829 ILJ 406 (LC)

SACCAWU v Pep Stores 199819 ILJ 939 (CCMA)

SAMWU obo Abrahams v City of Cape Town 201111 BLLR 1106 (LC) 
SATAWU v Collet Armed Security Services CC 2013 ZALCJHB 301

Stocklush (Pty) Ltd t/a Meadow Meats v FAWU obo Setouto 2015 ZALCCT 61

Tawusa obo Tau v Barplats Mine Ltd (Crocodile River Mine) 200930 ILJ 2791 (LC)

True Blue Foods Ltd t/a Kentucky Fried Chicken (KFC) v CCMA 20152 BLLR 194 (LC)

Western Refinery Ltd v Hlebela 201536 ILJ 2280 (LAC)

Zondi v The President of the Industrial Court 19978 BLLR 984 (LAC)

\section{List of Abbreviations}

Berkeley J Emp \& Lab L Berkeley Journal of Employment and Labor Law

CLL

Contemporary Labour Law

ILJ Industrial Law Journal

ILJ (UK) Industrial Law Journal (United Kingdom)

Md L Rev

Maryland Law Review

SALJ

South African Law Journal

UCLA L Rev

University of California at Los Angeles Law Review

Yale LJ

Yale Law Journal 